(RESEARCH ARTICLE)

\title{
Morpho-anatomical characteristics and antimicrobial activity of crude extract of Tephrosia villosa (L.) Pers. growing on sandy soil of Phan Thiet City, Binh Thuan Province, Vietnam
}

\author{
Pham Thi Nga ${ }^{1}$, Nguyen Thi Anh Linh ${ }^{1}$, Pham Van Ngot ${ }^{1}$ and Dang Thi Ngoc Thanh ${ }^{2, *}$ \\ ${ }^{1}$ Faculty of Biology, HCMC University of Education, 280 An Duong Vuong Street, Ward 4, District 5, Ho Chi Minh City. \\ 2 Faculty of Natural Science Pedagogy, Sai Gon University, 273 An Duong Vuong Street, Ward 3, District 5, Ho Chi Minh \\ City, Vietnam
}

Publication history: Received on 09 December 2020; revised on 16 December 2020; accepted on 18 December 2020

Article DOI: https://doi.org/10.30574/wjarr.2020.8.3.0471

\begin{abstract}
Tephrosia villosa (L.) Pers. is an herb species distributed mainly in arid sandy lands of the South Central Coast of Vietnam, including Binh Thuan province. The existing Vietnamese folk remedies have mentioned the medicinal effects of this herb in the treatment of edema and diabetes. Documents available in Vietnam provided only basic information on the morphology of this species. Therefore, this study aimed to investigate the morphological and anatomical characteristics of stems, leaves and roots of the plants in the analysis of relation to climatic conditions of the region. Antibacterial activity was initially studied as a basis for subsequent pharmacological studies. The crude ethanolic extracts were tested for inhibitory against Pseudomonas aeruginosa and Staphylococcus aureus by agar well diffusion method. The results showed that the plants had formed the morpho-anatomical characteristics to adapt to strong wind, strong light, high temperature, and dry sandy soils of the region. The ability to inhibit the two mentioned bacteria via the diameters of the halo was $10.8-12.7 \mathrm{~mm}$, respectively. The recommendation was to continue to study the anatomical characteristics of the primary roots to complete the data and further investigate the antibacterial and antifungal activities of extracts of Tephrosia villosa.
\end{abstract}

Keywords: Agar well diffusion; Binh Thuan province; Ethanolic extract; Morpho-anatomical characteristics; Tephrosia villosa

\section{Introduction}

Tephrosia villosa (L.) Pers. is a species of legume that grows wild in some dry parts of tropical and subtropical African and Asian countries [1]. In addition to its green manure effect, this plant is also known for its use as an insecticide, anthelmintic and antipyretic agent, and for treating diseases such as stomachache, dropsy, leprosy [2, 3]. In Vietnam, Tephrosia villosa has a local name "đoản kiếm lông" for the shape of a fruit like a short sword (đoản kiếm) covered by silky hairs (lông). This herb is mainly distributed in the dry, sandy land of Phan region (belongs to Ninh Thuan and Binh Thuan provinces today) and has been used in folk remedies to treat dropsy and diabetes [4, 5].

In Vietnam, in the target of searching for natural herbs to replace synthetic chemicals in disease treatment, many researches on morphological and anatomical characteristics of the medicinal plants has been conducted. Resources investigation of the Nation Institute of Medicinal Materials in years 2001 - 2005 showed the result of 3,948 species of plants and mushroom have been used as medicine [6]. However, the data on Tephrosia villosa is still simple, mainly describing the outward morphology and some uses as mentioned in Pham [4,5]. The present study has performed the analysis of morphological and anatomical traits in combination with the adaptability of the plant to climatic and soil

\footnotetext{
* Corresponding author: Dang Thi Ngoc Thanh

Faculty of Natural Science Pedagogy, Sai Gon University, 273 An Duong Vuong Street, Ward 3, District 5, Ho Chi Minh City, Vietnam. 
characteristics where Tephrosia villosa distributes. The antimicrobial activity with the crude alcohol extract of the aerial part of the plant was also tested for in vitro antibacterial property based on the literature's suggestion of resistance to bacterial disease (leprosy) $[3,4]$ and the exist of defensin, a small antimicrobial peptide participates in the innate immunity system in plants [2]. This study contributes to data on Tephrosia villosa to avoid confusion with similar plant species in collecting and using as well as standardization of this medicinal plant.

\section{Material and methods}

This research work was carried out at the Ecology-Botany laboratory of the Faculty of Biology, HCMC University of Education and the Biochemistry-Microbiology laboratory of Saigon University from July 2019 to October 2020.

\subsection{Samples collection and preparation}

Binh Thuan belongs to the South Central Coast of Vietnam with geographical coordinates from $10^{\circ} 33^{\prime} 42^{\prime \prime}$ to $11^{\circ} 33^{\prime} 18^{\prime \prime}$ north latitude, from $107^{\circ} 23^{\prime} 41^{\prime \prime}$ to $108^{\circ} 52^{\prime} 18^{\prime \prime}$ east longitude. Sandy soils and sandbars cover $18.22 \%$ of the natural area of Binh Thuan province [7] and these soils are home to Tephrosia villosa species. Phan Thiet City is the capital of Binh Thuan, located $183 \mathrm{~km}$ south of Ho Chi Minh City according to National Road 1A; in which Tien Thanh ward is located at the southernmost tip of the city [7] (Figure 1).

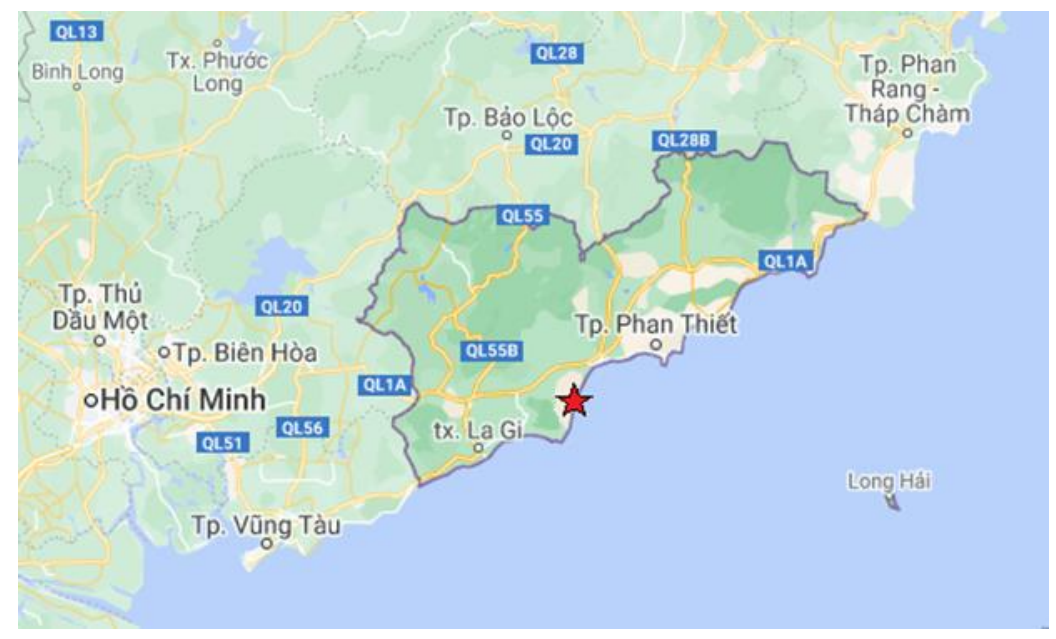

Figure 1 The map of Binh Thuan province [7] and the locate of Phan Thiet city Star shape used to illustrate Tien Thanh ward where samples were taken

Fifteen plant samples were collected from 5 sites in Tien Thanh ward, 3 plants per site. Soil samples were also collected at the 5 sites. Soils were taken at the $0-30 \mathrm{~cm}$ and $30-60 \mathrm{~cm}$ layer as described in the Vietnamese National Standards TCVN 8551: 2010 and TCVN 7538-2: 2005TC [8]. Plant and soil samples were transferred into sterile plastic bags, sealed, labelled, refrigerated and transported immediately to the laboratory. Fresh plant samples were stored in a refrigerator at $5^{\circ} \mathrm{C}$ for use in morphology study, and then preserved by immersion in formalin $5 \% \mathrm{v} / \mathrm{v}$ solution for continued use in anatomy study.

\subsection{Analyzing some physical and chemical criteria of soil}

Soil particles were analysed according to the Vietnamese National Standards TCVN 8941-2011 (soil texture) and TCVN 8567-2010 (soil organic matter) [8] by the Institute of Agricultural Science for Southern Vietnam, Ho Chi Minh City. Soil salinity was determined through electronic conductivity (EC) measurements as described by the Soil and Fertilizer Research Institute [9]. Acidity of soil via $\mathrm{pH}_{\mathrm{H} 20}$ and $\mathrm{pH}_{\mathrm{KCl}}$ was determinated as described in [9].

\subsection{Analyzing morphological and anatomical characteristics of plants}

\subsubsection{Analyzing morphological characteristics}

The collected plants were analysed for confirmation as Tephrosia villosa plants based on the literature [4, 10]. The shapes of plants and basic morphological features of the vegetative and reproductive organs of the plants corresponding different periods were described on site then they were recorded and taken photographs. Thereafter, the separate parts of the plant continued to be further analysed in the botanical laboratory $[11,12]$. 


\subsubsection{Analyzing anatomical characteristics}

Select leaves of average age ( 3 rd and 4th leaves from the top of tree) to determine type of stomata according to collodion film method [11]. After being wiped off the dirt, the leaves were applied a layer of collodion to the adaxial and abaxial surfaces. When the collodion layers dried, films were formed which were removed from the leaves and studied under a microscope. The quantity of stomata was determined with the help of a gridded glass slide (Wildco Gridded SedgewickRafter Counting Cell). Thin slices of leaves, stems, and roots were produced by using razor blade and were stained with methylene blue and carmine alum [12]. The tissue slides were observed and measured by using a microscope with eyepiece and stage micro-meters (Olympus).

\subsection{Investigation of the antibacterial ability of crude plant extract}

\subsubsection{Preparation of crude alcoholic plant extract}

The aerial parts (stems and leaves) of the medium-age Tephrosia villosa plant dried at $60^{\circ} \mathrm{C}$ until constant mass were ground into fine powder. To obtain the ethanol extract, dry powder was soaked in absolute ethanol at a ratio of 1:3 (w/v) for 48 hours under room temperature. After soaking, the supernatant was collected after flowing through the filter paper and the residue continued to be soaked in alcohol as described above. The process was repeated again to ensure maximum recovery of the substances contained in plant powder. To remove solvents, all volume of the extract was concentrated completely by using a rotary evaporator (Rotary Evaporator RE301, Yamato Scientific). The extraction efficiency was percentage by mass of extract relative to mass of original dry powder (w/w) [13].

\subsubsection{Investigation of the antibacterial ability}

The antimicrobial assay was performed according to agar well diffusion method [14]. The medium LB Agar was inoculated bacterial suspension to form concentration of $5 \times 10^{\wedge} 6 \mathrm{CFU}$ and poured into the Petri plates. Four wells was prepared in each plate by using a sterile steel round pipe $(\Phi=0.6 \mathrm{~cm})$. Each of $20 \mu \mathrm{l}$ of the test compound $\left(70^{\circ}\right.$ alcoholsoluble extract with concentration of $10 \mathrm{mg} / \mathrm{ml}$; positive and negative controls) was injected into each well. The plates were incubated for 48 hours at $37^{\circ} \mathrm{C}$. Results were obtained by measuring the inhibitory zone diameter. Positive control was gentamycin $(0.5 \mathrm{mg} / \mathrm{mL})$ (Gentamicin Sulfate - Gentamicin 80mg/2mL - DOPHARMA, Vietnam); negative control was alcohol $70^{\circ}$. Tested bacteria were Pseudomonas aeruginosa and Staphylococcus aureus provided by the Biotechnology Research and Development Institute, Can Tho University

\section{Results and discussion}

\subsection{Soil and environment characteristics where the plant Tephrosia villosa grew}

The species grew and developed in the following conditions: poor nutrition of sandy soil, poor water holding capacity; low rainfall $(1,024 \mathrm{~mm} /$ year), windy and sunny [7]. Figure 2 showed the landscape where the tree growing and soil profile in Tien Thanh commune at the sampling site
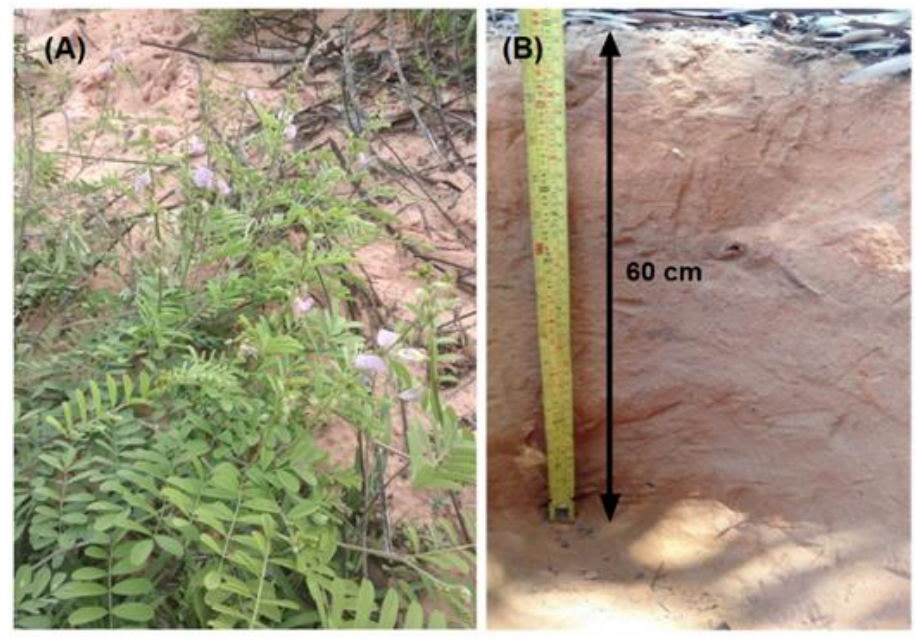

Figure 2 The landscape (A) and soil profile (B) where the species Tephrosia villosa grew 
The soil sampled was light red sand dune soil. The top layer of $30 \mathrm{~cm}$ thick was sandy soil, discrete, light red, mixed with many tree roots. The layer at a depth of $30-60 \mathrm{~cm}$ was sandy soil, yellow reddish, moist and tighter, mixed with few roots. The proportion of sand in the soil accounts for $96 \%$ correspond for the water holding capacity was poor. The soil nutrition was poor with low organic matter content (0.32-0.42\%). The soil salinity was insignificant with EC below 2 $\mathrm{dS} / \mathrm{m}$. pH was slightly acidic $(\mathrm{pH} \mathrm{KCl}>5.5)$ that did not affect to the plant's nutrient absorption (Table 1).

Table 1 Some physical and chemical criteria of soil samples

\begin{tabular}{|l|l|l|l|}
\hline \multicolumn{2}{|c|}{ Criteria of soil } & $0-30$ cm soil layer & $\mathbf{3 0}-\mathbf{6 0}$ cm soil layer \\
\hline \multirow{4}{*}{ Soil particles } & Sand (\%) & 96 & 96 \\
\cline { 2 - 4 } & Silt (\%) & 1 & 2 \\
\cline { 2 - 4 } & Clay (\%) & 3 & 6 \\
\cline { 2 - 4 } & Organic matter (\%) & 0.32 & 0.42 \\
\hline \multirow{3}{*}{ Soil acidity } & pHкCl & 5.58 & 5.58 \\
\cline { 2 - 4 } & pHн20 & 6.37 & 6.77 \\
\hline Soil salinity & EC $(\mathrm{dS} / \mathrm{m})$ & 0.32 & 0.36 \\
\hline
\end{tabular}

\subsection{Morphological characteristics of the plant Tephrosia villosa}

\subsubsection{Morphological characteristics of vegetative organs}

The plant belonged to the type of annual or perennial bushy herb, about one-meter high, with many branches spread out close to the ground. The leaves were odd-pinnate compound leaves, about $10-15 \mathrm{~cm}$ long, with $9-13$ leaflets. Each leaflet was about $1 \mathrm{~cm}$ long and $0.5 \mathrm{~cm}$ wide, obovate in entire blade, slightly indented and had a short pin at the tip. Each compound leaf had a pair of long upright triangular stipules about $1-2 \mathrm{~mm}$ long at the base. All leaves as well as young branches covered with a silvery layer of silky hairs (trichomes). The plant had a separated root system with many branching secondary roots. Some root nodules presented on the young roots. (Figure 3)
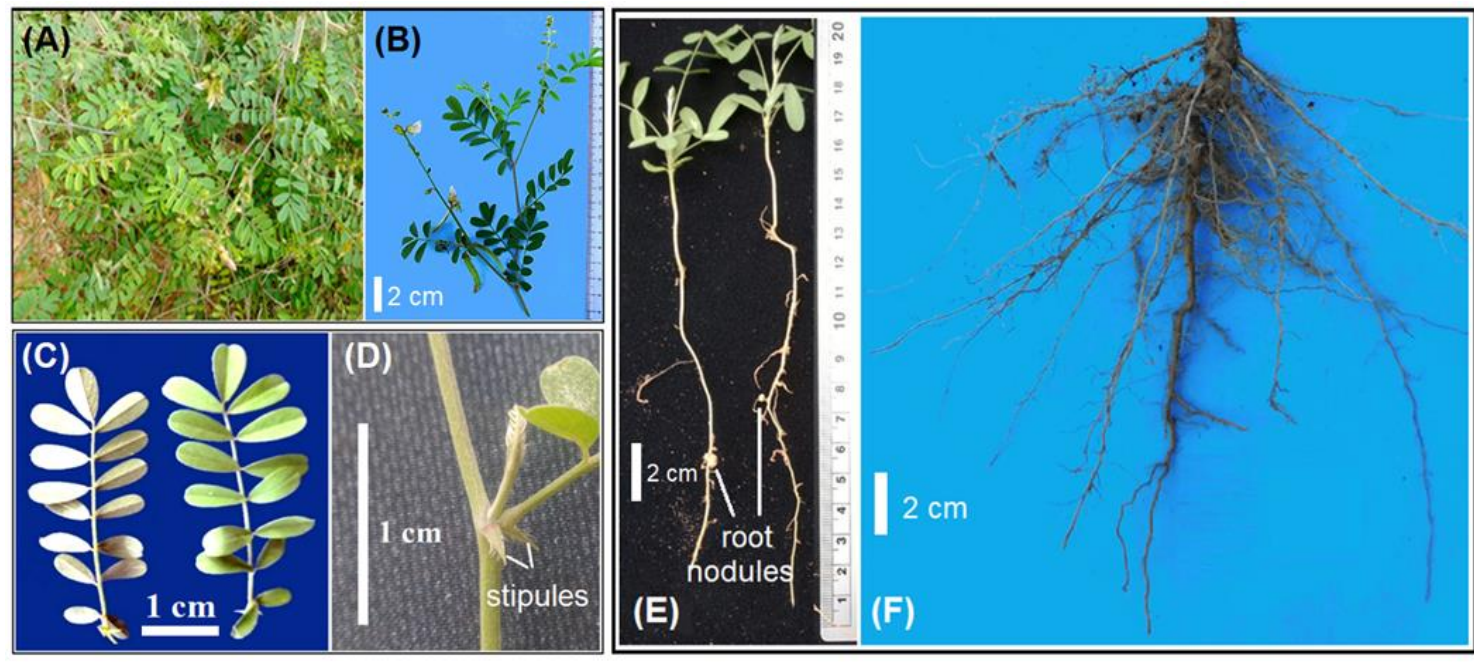

Figure 3 The shape of the plant Tephrosia villosa (A and B); and morphology of leaf (C and D) and root (E and F)

\subsubsection{Morphological characteristics of reproductive organs}

The flower cluster of the species was a panicle (much-branched inflorescence), $6-12 \mathrm{~cm}$ long, consisting of $12-26$ flowers. Each branch of the panicle was a small raceme with short rachis bearing $1-3$ flowers. The inflorescence originated from the lateral or apical meristem. The inflorescence belonged to bracteates type with the bract in each flower were reduced to a small scale. In particular, the lateral buds at 1st to 3rd leaf axils near the top of the tree only developed to non-peduncle flower clusters that had only $1-2$ growing flowers. The inflorescence, sepals and the outer surface of the standard petal covered with trichomes. Flower of the plant was bisexual, about $2 \mathrm{~cm}$ long, and had a short 
pedicel with small bract. Flower of the plant was bisexual, about $2 \mathrm{~cm}$ long, and had a short pedicel with small bract. Calyx was green, hairy, fused at the base, and had 5 sepals about $7-8 \mathrm{~mm}$ long. Corolla was pinkish purple and had vertical stripes. It had typically papilionaceous with 5 petals being descending imbricate: one banner (standard), two wings and 2 joined keels. The standard petal was yellowish and hairy at the base. The keels was somewhat coiled. An androecium was enclosed within the keels, $1.5 \mathrm{~cm}$ long, and diadelphous (9), 1. The posterior stamen was free and filaments of the rest 9 stamens fused to form a tube. All of the anthers were facing out. The gynoecium was comprised of one carpel. The ovary was superior, green, and elongated with a style that was long, bend at the tip and terminated with a stigma. The ovary had one chamber contained many ovules with placentation was marginal. The pod was slightly flat, shaped like a short sword, covered with yellowish trichomes, and became slightly arched when it was old. The ripen pod was $3-5 \mathrm{~cm}$ long and $0.3-0.4 \mathrm{~cm}$ wide, still kept the calyx, split into 2 slightly curled peel pieces to show out $5-8$ blackish green, kidney-shaped seeds.

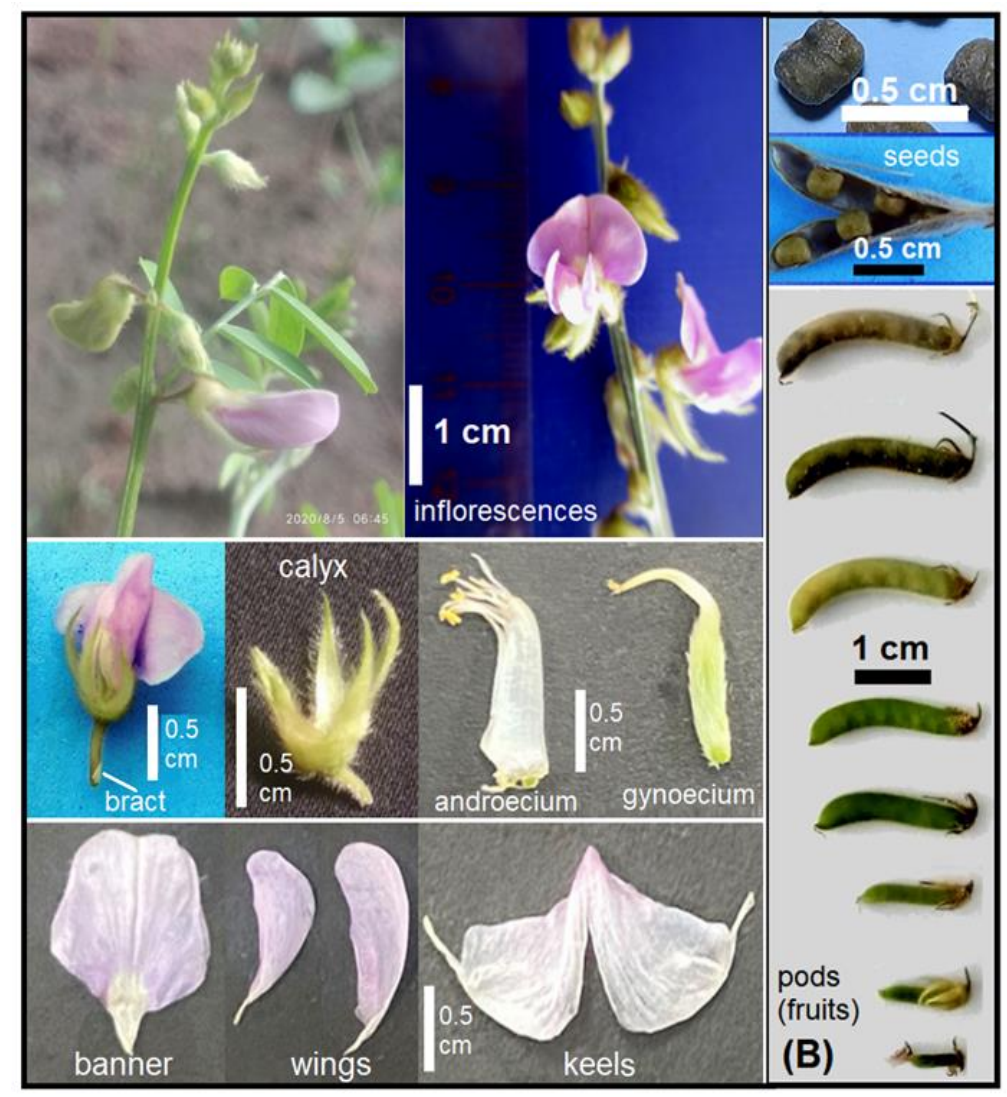

Figure 4 Morphology of reproductive organs of the plant Tephrosia villosa

In terms of adaptive morphology, field observations had shown that the plant Tephrosia villosa had early branching and the branches located close to the ground. These characteristics helped the plant did not break down in high winds of the coastal areas. In addition, the plant had developed a deep and widespread root system that helped it stood up and absorbed more water and mineral salts from the poor soil. These features were also found in some plants such as Polycarpaea rosulans (Gagnep.), Indigofera glabra (L.), Indigofera nummulariifolia (L.) (Alston), Zornia gibbosa (Span.) as described in [15]. In terms of morphology, as mentioned above, the result showed that the plant Tephrosia villosa did not have the raceme inflorescence as some authors had described $[3,4,5,10]$ but instead was the panicle inflorescence with 1 - 3 flowers per a raceme. These features would contribute to a more accurate description and identification for the plant.

\subsection{Anatomical characteristics of the plant Tephrosia villosa}

\subsubsection{Anatomical characteristics of stems}

The result of microanatomy showed that the primary stem had a quadrilateral shape with slightly wavy margin. The epidermis consisted of a layer of small, unequal polygons cells that fit closely together. The outside of the epidermis had a thick cutinized layer and many unicellular epidermal trichomes that protected and helped reduce the release of water vapor. In addition, the epidermis had some scattered glandular trichome and stomata (Figure 5). 

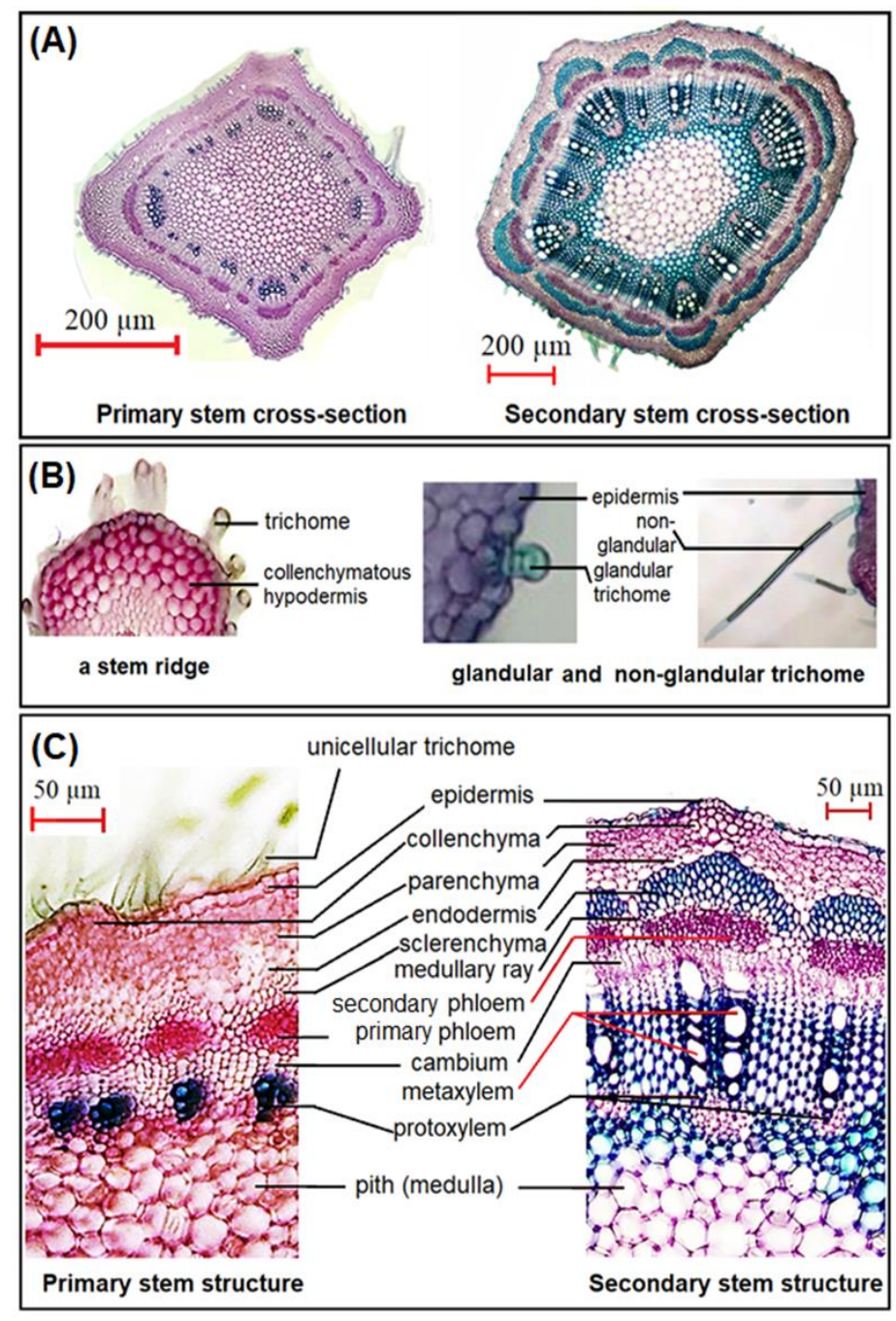

Figure 5 Anatomy of stems of the plant Tephrosia villosa

(A) Cross-section of primary and secondary stems; (B) Some of specific structure; (C) Detailed structure of stems.

The primary cortex consists of $3-4$ thick collenchyma layers consisted of unequal polygons cells fit closely together. This structure also was known as multilayered collenchymatous hypodermis that given mechanical strength to the stem, especially at ridges. Below the hypodermis, 4-5 parenchyma layers were present with spherical cells without chloroplasts, and conspicuous intercellular spaces. Endodermis was a layer of cells with a polyhedron shape slightly extending in a tangential direction, and larger than the parenchyma cells.

The stele accounted for $2 / 3$ of the section thickness. The pericycle (bundle cap) located between the endodermis and vascular bundles in the form of $3-4$ layers of polyhedron sclerenchyma cells that had thick secondary walls. The vascular bundles arranged around the pith. Each bundle consisted of the outer proto-phloem and the inner primary xylem that developed in the centrifugal direction. Between the primary phloem and xylem, the proto-cambium was present with $4-8$ layers of cells fit closely arranged in concentric or radial directions to form a continuous circle. The pith (medulla) located in the center of the stem, was composed of large parenchyma cells with small intercellular spaces.

The section of the secondary stem had a polygonal shape with a slightly undulating margin. In the term of anatomy, the secondary stem also included the epidermis, the cortex, and the stele that was similar to the primary body but had some changes as follows. Below the epidermis, the parenchyma developed into $5-6$ layers of cells. The pericycle turned hard tissue early, forming many groups of sclerenchyma cells arranged in arcs separated by parenchyma cells. Inside the sclerenchyma was the secondary phloem with $3-6$ layers of polyhedron cells arranged in bundles and separated by medullary rays consisted of large parenchyma cells arranged in radial direction. In term of secondary xylem, metaxylem formed and developed into a continuous ring and pushed fiber element and parenchyma of the primary xylem inwards. 
The dimensions of the components that made up the primary and secondary stems of the plant Tephrosia villosa shown in Table 2 below. Thereby, it showed that the epidermis, cortex and endodermis had almost no increase in size. On the contrary, the secondary stele thickness increased by about 4 folds compared to the primary. In particular, the phloem, the xylem and the medulla increased by 2.6 folds, 8.4 folds, and 4.3 respectively compared to the original.

Table 2 Dimensions of components of primary and secondary stems

\begin{tabular}{|l|l|l|l|l|}
\hline \multirow{2}{*}{ Components } & \multicolumn{3}{|l|}{ Primary stem } & \multicolumn{2}{l|}{ Secondary stem } \\
\cline { 2 - 5 } & Thickness $(\boldsymbol{\mu m})$ & Percentage & Thickness $(\boldsymbol{\mu m})$ & Percentage \\
\hline Cuticle & $1.92 \pm 0.19$ & 0.67 & $1.98 \pm 0.10$ & 0.23 \\
\hline Epidermis & $16.86 \pm 0.99$ & 5.88 & $17.79 \pm 2.09$ & 2.02 \\
\hline Cortex parenchyma & $58.05 \pm 7.77$ & 20.26 & $60.51 \pm 8.68$ & 6.88 \\
\hline Endodermis & $17.09 \pm 1.22$ & 5.96 & $18.04 \pm 0.80$ & 2.05 \\
\hline Sclerenchyma & $36.61 \pm 5.45$ & 12.78 & $62.49 \pm 8.57$ & 7.11 \\
\hline Phloem & $21.40 \pm 2.83$ & 7.47 & $55.10 \pm 2.60$ & 6.27 \\
\hline Cambium & $24.09 \pm 3.13$ & 8.41 & $27.55 \pm 1.35$ & 3.13 \\
\hline Proto-xylem & $38.13 \pm 4.86$ & 13.31 & $275.51 \pm 13.46$ & 31.33 \\
\hline Meta-xylem & - & - & $48.01 \pm 2.20$ & 5.46 \\
\hline Medullary parenchyma & $72.40 \pm 11.03$ & 25.27 & $312.34 \pm 36.58$ & 35.52 \\
\hline Total & $286.55 \pm 37.47$ & 100 & $879.32 \pm 35.03$ & 100 \\
\hline
\end{tabular}

Number of samples: $\mathrm{n}=15$. Thickness calculated in radius of cross-section. (-): Not present

\subsubsection{Anatomical characteristics of leaflets}

The general view of the cross-section of petiole was egg with two small symmetrical ridges were semicircle in shape at adaxial sides. The petiole structure closely resembled the primary stem. The epidermis had a thick cuticle, some stomata and trichomes covering the outside. The primary cortex was thin $(91.43 \mu \mathrm{m})$ and the stele accounted for most of the cross section $(252.12 \mu \mathrm{m}$ in radius). The primary cortex included of developed palisade tissue with $4-5$ polyhedron cells layers extending in the radius direction. At the ridges, the palisade tissue replaced by collenchyma with $4-5$ layers of polyhedron cells with thick walls to perform mechanical functions.
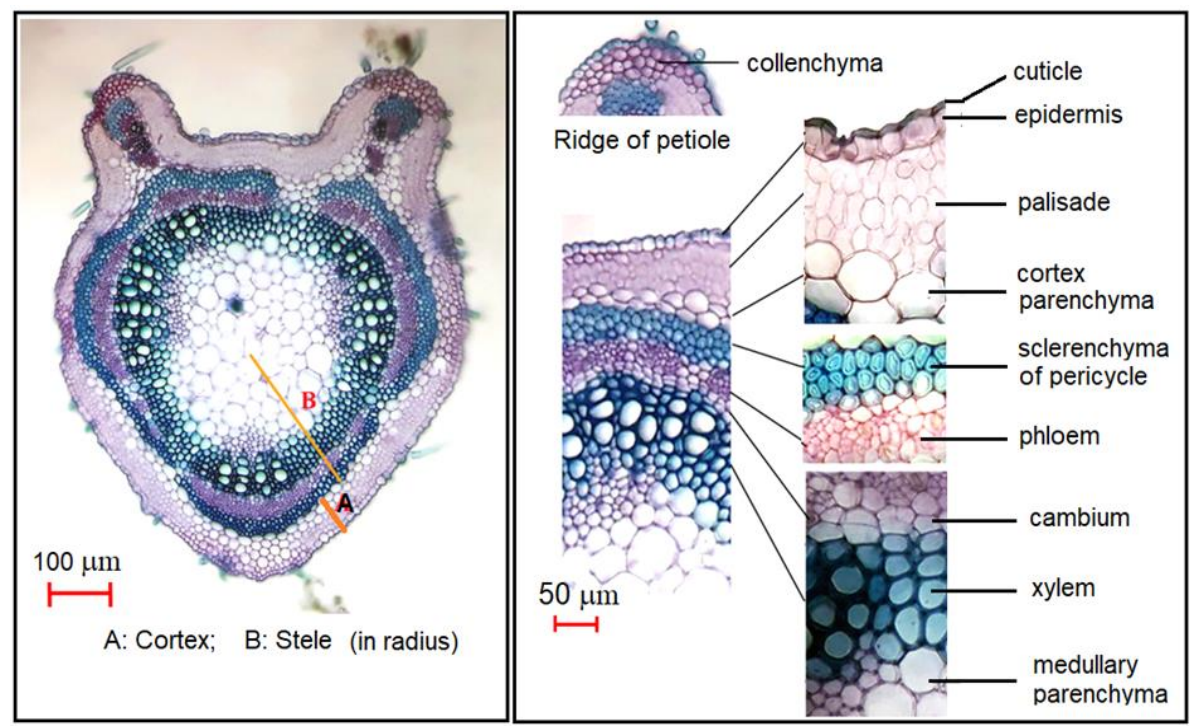

Figure 6 Cross-section (left) and detailed structure of the leaflet petiole of Tephrosia villosa (right) 
The cortex parenchyma consists of 2- 3 layers of large of spherical or polyhedron cells. Most parenchyma cells at the layer adjacent to the collenchyma elongated in tangential directions. The outer ring turned to early hard tissue, consisting of $3-4$ layers of sclerenchyma cells. The vascular bundles arranged a nearly continuous ring with the xylem developing inside and the phloem adjacent to the pericycle outside. Vascular bundles also appeared at the two ridges with the presence of $1-2$ small bundles. The medulla was composed of spongy parenchyma cells with small intercellular spaces (Figure 6).

The leaflet had a bifacial structure. Both the adaxial and abaxial epidermis had cuticle, unicellular epidermal trichomes and stomata. The stomata were anomocytic (irregular celled) with a density of $204 / \mathrm{mm} 2$ on the adaxial and $143 / \mathrm{mm} 2$ on the abaxial (Figure 7).

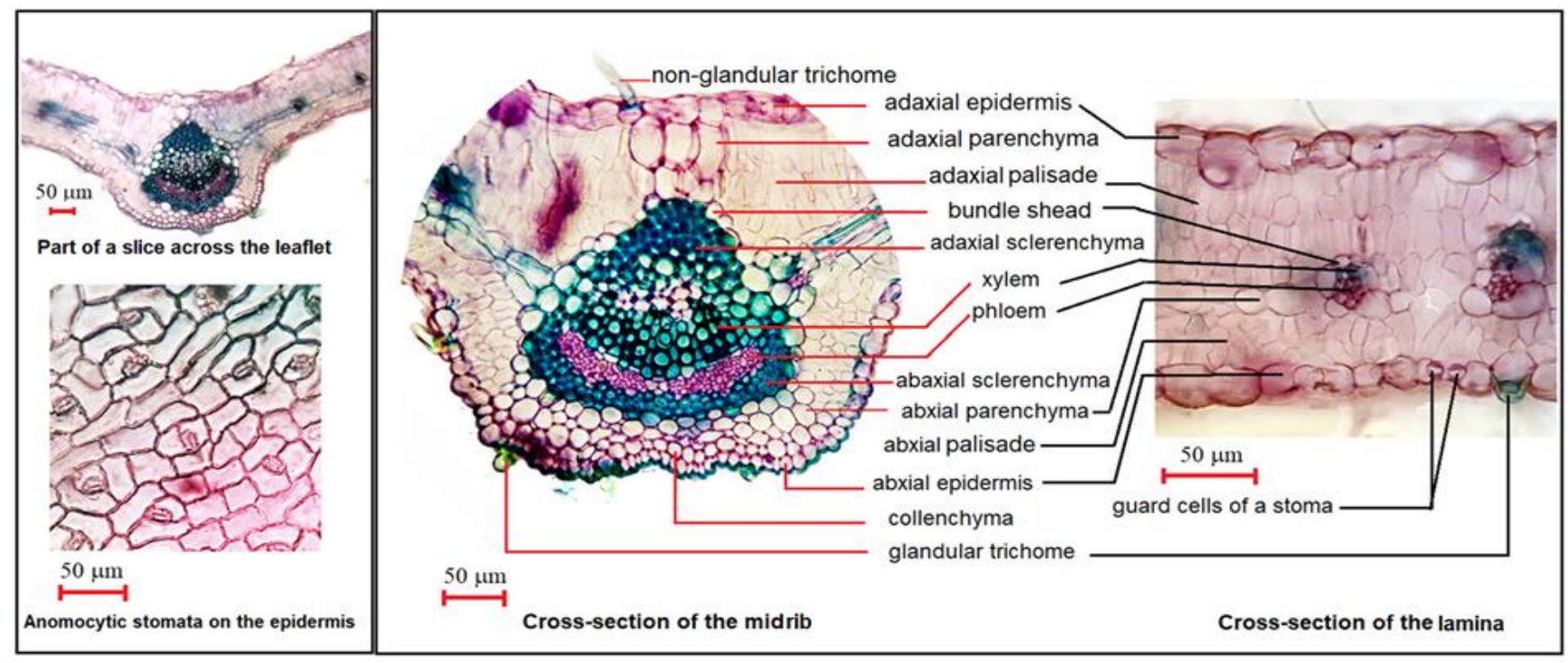

Figure 7 Cross-section of the leaflet and type of stomata (left), and detailed structure of the midrib and lamina of Tephrosia villosa (right)

The midrib of each leaflet was flat on the adaxial surface, convex and slightly wavy on the abaxial. Adjacent to the adaxial epidermis were 2 - 3 layers of parenchyma cells of large size with the two sides were palisade cells extending to the sides of the leaflet blade (lamina). Adjacent to the lower epidermis were $2-3$ layers of parenchyma interspersed with smaller collenchyma cells present in the ridges. The cross section of the midrib vascular bundle was triangular. The bundle sheath consisted of a layer of parenchyma cells on the outside with its inner junction was a few layers of sclerenchyma cells that distributed at the vertex and the base. The center of the vascular bundle had xylem distributed on the vertex and phloem arranged in an arc at the base side.

For the leaflet blade, the palisade mesophyll developed on both the adaxial and abaxial, accounting for $78.81 \%$ of the thickness of the lamina. The adaxial palisade was about $71.28 \mu \mathrm{m}$ thick, consisting of $2-4$ layers of cells that extend vertically and fit closely together. The abaxial palisade that replaced the spongy tissue was about $24.72 \mu \mathrm{m}$ thick, consisting of 2 - 3 layers of cells with diverse shapes and arranged quite closely together. There was a layer of parenchyma cells extending horizontally between the upper and lower palisade. In the lamina, there were also lateral veins and veinlets. Each vascular bundle surrounded by a cell layer of bundle sheath with $2-4$ xylem cells and $6-8$ phloem cells inside. The dimensions of components of the petiole, main vein and leaf blade shown in Table 3. 
Table 3 Dimensions of components of primary and secondary stems

\begin{tabular}{|c|c|c|c|c|c|c|}
\hline \multirow[t]{2}{*}{ Components } & \multicolumn{2}{|l|}{ Petiole } & \multicolumn{2}{|l|}{ Midrib } & \multicolumn{2}{|l|}{ Lamina } \\
\hline & $\begin{array}{l}\text { Thickness (a) } \\
(\mu \mathrm{m})\end{array}$ & Percentage & $\begin{array}{l}\text { Thickness }{ }^{(b)} \\
(\mu \mathrm{m})\end{array}$ & Percentage & $\begin{array}{l}\text { Thickness }{ }^{(b)} \\
(\mu \mathrm{m})\end{array}$ & Percentage \\
\hline Cuticle & $\begin{array}{l}3.05 \pm 0.72 \\
-\end{array}$ & $\begin{array}{l}0.83 \\
-\end{array}$ & $\begin{array}{l}2.92 \pm 0.35 * \\
3.26 \pm 0.48 * *\end{array}$ & $\begin{array}{l}0,93 \\
1.03\end{array}$ & $\begin{array}{l}3.23 \pm 1.00 * \\
3.20 \pm 0.82 * *\end{array}$ & $\begin{array}{l}2.11 \\
2.09\end{array}$ \\
\hline Epidermis & $12.17 \pm 2.89$ & 3.33 & $\begin{array}{l}17.92 \pm 2.29 * \\
13.31 \pm 2.52 \text { ** }\end{array}$ & $\begin{array}{l}5.68 \\
4.22\end{array}$ & $\begin{array}{l}11.91 \pm 1.95 * \\
11.74 \pm 1.79 * *\end{array}$ & $\begin{array}{l}7.76 \\
9.74\end{array}$ \\
\hline $\begin{array}{l}\text { Adaxial } \\
\text { palisade }\end{array}$ & $54.43 \pm 5.80 *$ & 14.90 & - & - & $71.28 \pm 6.64 *$ & 46.46 \\
\hline $\begin{array}{l}\text { Abaxial } \\
\text { palisade }\end{array}$ & - & - & - & - & $24.72 \pm 4.45^{* *}$ & 22.35 \\
\hline Parenchyma & $21,79 \pm 2,05^{* *}$ & 11,93 & $36.87 \pm 3.26 *$ & 11.69 & $9.57 \pm 2.44^{* *}$ & 9.50 \\
\hline Bundle sheath & - & - & $16.49 \pm 3.35$ & 5.23 & - & - \\
\hline $\begin{array}{l}\text { Pericycle } \\
\text { sclerenchyma }\end{array}$ & $\begin{array}{l}26.57 \pm 6,96 \\
-\end{array}$ & $\begin{array}{l}7.27 \\
-\end{array}$ & $\begin{array}{l}69.20 \pm 10.40 * \\
33 ., 80 \pm 4.26 \text { ** }\end{array}$ & $\begin{array}{l}21.94 \\
10.72\end{array}$ & - & $\begin{array}{l}- \\
-\end{array}$ \\
\hline Phloem & $31.91 \pm 2.61$ & 8.73 & $24.44 \pm 3.29$ & 7.75 & - & - \\
\hline Cambium & $15.95 \pm 1.31$ & 4.37 & - & - & - & - \\
\hline Xylem & $63.82 \pm 5.22$ & 17.47 & $76.41 \pm 14.38$ & 24.23 & - & - \\
\hline $\begin{array}{l}\text { Medullary } \\
\text { parenchyma }\end{array}$ & $113.87 \pm 18.49$ & 31.17 & - & - & - & - \\
\hline Collenchyma & - & - & $20.74 \pm 2.82 * *$ & 6.58 & - & - \\
\hline Total & $343.55 \pm 22.98$ & 100 & $315.39 \pm 17.93$ & 100 & $135.64 \pm 8.44$ & 100 \\
\hline
\end{tabular}

(a): Thickness calculated in radius of cross-section. (b): Thickness calculated in whole of cross-section. $\left({ }^{*}\right)$ : Adaxial. $\quad\left(^{* *}\right)$ : Abaxial

\subsubsection{Anatomical characteristics of roots}

The microscopic structure of Tephrosia villosa roots was shown in Figure 3 below.

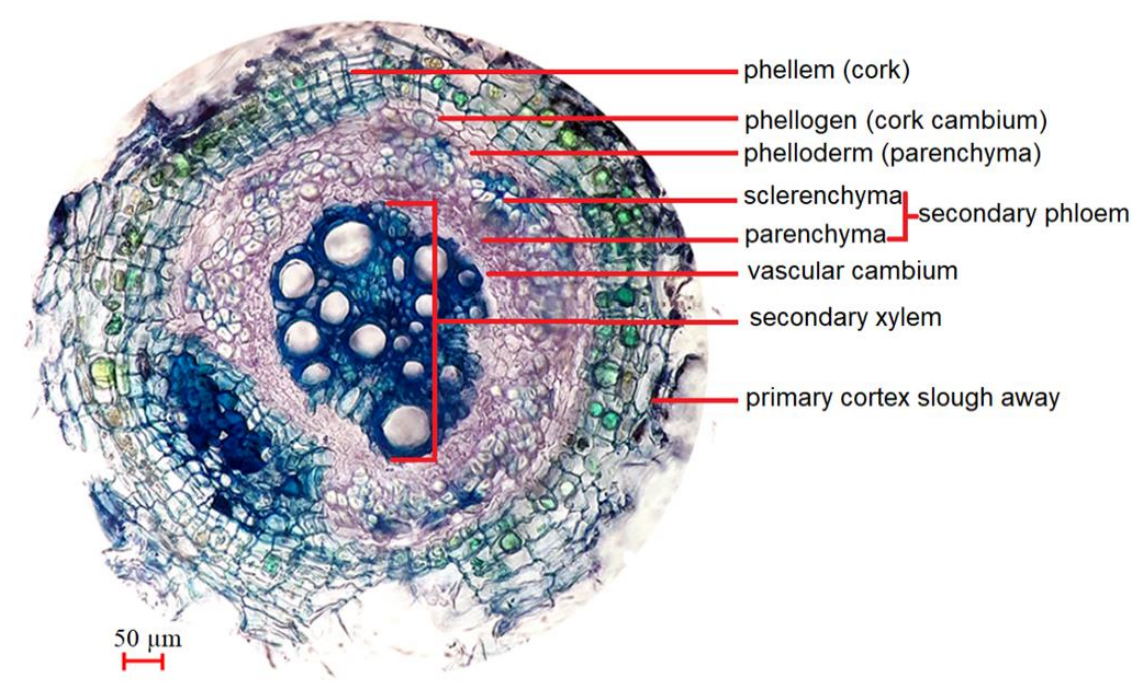

Figure 8 The secondary structure of the root of Tephrosia villosa 
Going from the outside in, the first secondary structure of the roots was the phellum (cork cells). This structure was about $64.87 \mu \mathrm{m}$ thick, consisted of $4-6$ layers of suberized cells arranged close together, formed by the phellogen tissue (cork cambium) inside. The phellogen derived from parenchyma of pericycle, consisted of a layer of cuboid cells fit close together. The phellogen also formed the phelloderm consisting of several layers of parenchymal cells that were adjacent to and interspersed with secondary phloem bundles arranged in arcs. The secondary phloem consists of the outer sclerenchyma cells and the inner parenchyma cells. The secondary xylem occupied the entire central core, consisting of vascular elements of meta-xylem and polyhedron cells of proto-xylem fit closely together. Separating the secondary phloem from the secondary xylem was the vascular cambium. There was no medullary parenchyma. The dimensions of components of the root shown in Table 4.

Table 4 Dimensions of components of the secondary root

\begin{tabular}{|l|l|l|}
\hline Components & Thickness $(\boldsymbol{\mu m})$ & Percentage \\
\hline Phellem & $64.87 \pm 4.04$ & 24.26 \\
\hline Phellogen & $9.01 \pm 0.64$ & 3.37 \\
\hline Phelloderm & $25.05 \pm 1.77$ & 9.37 \\
\hline Sclerenchyma of secondary phloem & $62.29 \pm 5.21$ & 23.30 \\
\hline Parenchyma of secondary phloem & $27.93 \pm 0.90$ & 10.45 \\
\hline Vascular cambium & $5.59 \pm 0.18$ & 2.09 \\
\hline Secondary phloem & $72.61 \pm 2.34$ & 27.16 \\
\hline Total & $267.35 \pm 15.08$ & 100 \\
\hline
\end{tabular}

Regarding adaptive anatomy, the research results showed that the entire surface of aerial parts had cuticles and trichomes that protected the plants from heat and limited water vapor loss. The surfaces of the primary stems also had folds that increased the ability of the stem to flex. The stems had ridges with inner collenchyma for increased mechanical strength. For the leaflets, on the upper of the midribs were large parenchyma cells storing water that could reduce the surface area of blade under dry conditions, thereby reducing exposure to light. The presence of collenchyma, sclerenchyma and mineral crystals in cells helped to increase the mechanical strength of the leaflets. Palisade mesophyll tissue developed, accounting for nearly $80 \%$ of the thickness of the leaf blade, which increased the photosynthetic efficiency. In the roots, the secondary structure had a developed cork layer that protected the internal structures. Secondary xylem grew to the entire medulla that increased water conduction to the plant. All of these features had observed in many plant species that grew in arid regions of Vietnam as adaptive features and stated by [15], [16].

This study also discovered some distinct structural features of Tephrosia villosa plants growing in Binh Thuan, Vietnam compared with this species plants growing in other lands. The stomata of Tephrosia villosa plants were anomocytic type instead of a combination of anomocytic and anisocytic types [3]. The density of the stomata were also higher: $204 / \mathrm{mm} 2$ on the adaxial epidermis and $143 / \mathrm{mm} 2$ on the abaxial epidermis, instead of $100 / \mathrm{mm} 2$ as shown in the document [3]. The Tephrosia villosa plants in this study also showed the presence of the periderm with cork and cork cambium, and of the sclerenchyma phloem which was not mentioned in [3]. However, more studies on Tephrosia villosa plants growing in other habitats as well as primary structure of the root of this plant need to conduct to refine the anatomical and adaptive data of this species.

\subsection{Antibacterial ability of the crude plant extract}

The extraction efficiency of ethanolic extract of Tephrosia villosa was $10.6 \%$ and the density of the extract was 1.12 $\mathrm{g} / \mathrm{ml}$. The results of antimicrobial activity of the ethanolic extract of Tephrosia villosa shown in Table 5 and Figure 9. The content of the extract and the antibiotic gentamicin in each well was $200 \mu \mathrm{g}$ and $10 \mu \mathrm{g}$, respectively. 


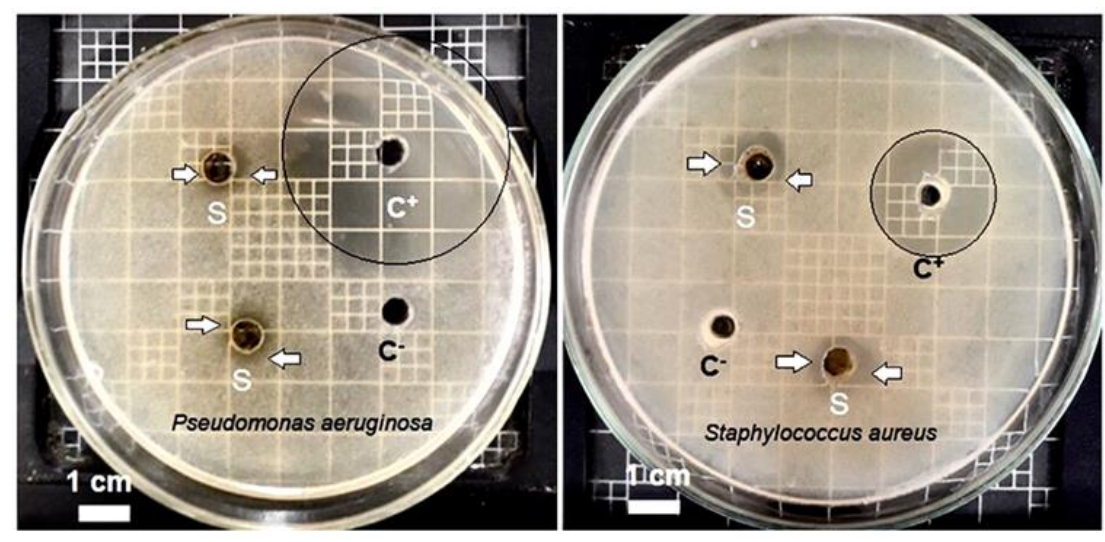

Figure 9 Zone of inhibition in the experiment of antibacterial activities of the Tephrosia villosa extract (C+): Positive control (gentamycin). (C-): Negative control (alcohol 70). (S): Sample (extract of Tephrosia villosa).

Table 5 Antibacterial activities of the ethanol extract of Tephrosia villosa stems and leaves

\begin{tabular}{|l|l|l|}
\hline \multirow{2}{*}{ Test samples } & \multicolumn{2}{l|}{ Zone of bacterial inhibition (mm) } \\
\cline { 2 - 3 } & P. aeruginosa & S. aureus \\
\hline Tephrosia villosa extract & $10.78 \pm 0.07$ & $12.68 \pm 0.06$ \\
\hline Gentamycin (Positive control) & $4.62 \pm 0.14$ & $2.38 \pm 0.09$ \\
\hline Alcohol $70^{\circ}$ (Negative control) & 0 & 0 \\
\hline \multicolumn{2}{|l|}{ Well diameter $-6 \mathrm{~mm}$. Tephrosia villosa extract $(200 \mu \mathrm{g} / \mathrm{well})$. Gentamicin $(10 \mu \mathrm{g} / \mathrm{well}) ;$}
\end{tabular}

The ability to inhibit Pseudomonas aeruginosa and Staphylococcus aureus via the diameters of the halo was 10.8 - 12.7 $\mathrm{mm}$, respectively. These results showed that Gram-positive bacteria were more sensitive to extracts than Gram-negative bacteria. This was also observed in some studies with respect to the antibacterial activities of Tephrosia bracteolata and many other medicinal plant extracts. However, the active substances in the extract should be isolated and further performed pharmacological evaluation.

\section{Conclusion}

This study has contributed to complete the description of morphological and anatomical adaptations of Tephrosia villosa $a$ in the dry climate of Binh Thuan province. Ethanolic extract from the stems and leaves of this plant has also been shown to inhibit the bacteria Pseudomonas aeruginosa and Staphylococcus aureus. This work paved the way for further studies of a Vietnamese folk medicinal plant, Tephrosia villosa [18], [19], [20].

\section{Compliance with ethical standards}

\section{Acknowledgments}

The authors would like to thank for the support of Saigon University and Ho Chi Minh City University of Education.

\section{Disclosure of conflict of interest}

All authors declare no conflicts of interest associated with this article.

\section{References}

[1] Plants of the World Online [Internet]. London: Royal Botanic Gardens Kew. (C) 2017; [cited 2020 Nov 15]. Available from: http://www.plantsoftheworldonline.org/.

[2] Zhang P, Qin D, Chen J, Zhang Z. Plants in the Genus Tephrosia: Valuable Resources for Botanical Insecticides. Insects. 21 Oct 2020; 11(10): 721. 
[3] Rajabudeen E, Ganthi AS, Subramanian MPS. Pharmacognostical Studies on Tephrosia villosa (L.) Pers. (Fabaceae). Research Journal of Pharmacognosy and Phytochemistry. October-December 2014; 6(4): 190-94.

[4] Pham Hoang Ho. Plants used as medicinal herbs in Vietnam. HCMC: Youth Publishing House; 2006. (Language: Vietnamese)

[5] Vo Van Chi. Vietnamese Medicinal Plants Dictionary, Volume 1. HCMC: Medical Publishing House. 2018. (Language: Vietnamese)

[6] Dang Ngoc Phuc, Le The Bien, Do Xuan Cam. Morphology and anatomy of the species Gelsemium elegans collected from Tay Giang district, Quang Nam, Viet Nam. In: Editorial board of the Proceeding of the 7th National Scientific Conference on Technology and Biological Resources (on 2017 Oct 20) eds. Scientific report on ecology and biological resources. Ha Noi: Natural and Applied Sciences Publishing House. 2017; 313-18.

[7] Binh Thuan Portal [Internet]. Binh Thuan: Binh Thuan Provincial People's Committee; (c) 2018 [cited 2020 Nov 15]. Available from: https://www.binhthuan.gov.vn/.

[8] Vietnamese National Standards - Technical regulations [Internet]. Hanoi: Portal electronic of the Ministry of Agriculture and Rural Development; (C) 2005 [cited 2020 Nov 15]. Available from: https://www.mard.gov.vn/.

[9] Soils and Fertilizers Research Institute. Handbook of soil, water, fertilizer, crop analysis. Hanoi: Agriculture Publishing House; 1998.

[10] Pham Hoang Ho. Plants of Vietnam, Volume 1. HCMC: Youth Publishing House. 1999. (Language: Vietnamese)

[11] Nguyen Nghia Thin. Methods of Plant Research, 2nd ed. Hanoi: Vietnam National University Publishing House. 2008.

[12] Tran Cong Khanh. Practice of plant morphology and anatomy. Hanoi: University and Professional High School Publishing House. 1981.

[13] Nguyen Kim Phi Phung. Methods of Isolation of Organic Compounds. HCMC: Vietnam National University Publishing House. 2007.

[14] Balouiri M, Sadiki M, Ibnsouda SK. Methods for in vitro evaluating antimicrobial activity: A review. Journal of Pharmaceutical Analysis. Apr 2016; 6(2): 71-79.

[15] Pham Van Ngot, Nguyen Thi Thu Ngan, Quach Van Toan Em. Study on adaptive characteristics of some plants in the sandy soil areas of Phan Thiet city, Binh Thuan province [Final report of scientific projects facility]. HCMC: Ho Chi Minh City University of Education. 2017.

[16] Duong Tien Thach, Phan Thi Dieu. Morphological and anatomical features related to adaptibility of some coastal rock plants in Nhon Ly commune, Quy Nhon city, Binh Dinh province. Journal of Science, Can Tho University. Aug 2018; 54(6A): 20-28.

[17] Nguyen Ba. Plant morphology, 2nd ed. Hanoi: Education Publishing House; 2005. (Language: Vietnamese)

[18] Egharevba GO, Dosumu 00, Oguntoye SO, Njinga NS, Dahunsi SO, Hamid AA, Anand A, Amtul Z, Priyankac U. Antidiabetic, antioxidant and antimicrobial activities of extracts of Tephrosia bracteolata leaves. Heliyon. Aug 2019; 5(8): e02275.

[19] Vlietinck AJ, Van Hoof L, Totte J, Lasure A, vanden Berghe D, Rwangobo PC, Mvukiyuniwami J. Screening of hundred Rwandese medicinal plants for antimicrobial and antiviral properties. Journal of Ethnopharmacology. Apr 1995; 46(1): 31-47.

[20] Rabe T, Van Staden J. Antibacterial activity of South African plants used for medicinal purposes. Journal of Ethnopharmacology. Mar 1997; 56: 81-87. 